Early Theatre 10.2 (2007)

DAVID MANN

\title{
Female Play-going and the Good Woman
}

Stephen Orgel argues of the Elizabethan theatre that 'all the sources agree that a large part of the audience were women', and hence 'the depictions must at the very least represent cultural fantasies, and women were implicated in them as well as men'. 'The women of the Renaissance stage', he concludes, apparently forgetting for a moment their mode of representation, 'must be as much emanations of ... self as the men are'. Richard Levin too argues that women were regarded as 'a constituency whose interests and feelings should be considered'. Linda Woodbridge goes as far as to suggest that in the second decade of the seventeenth century, women 'stalked the streets with pistols', and 'were using their economic and vocal power to influence the way women were presented onstage'. 'We do know,' claims Alison Findlay, 'that women made up a significant part of the Renaissance theatre audience'. ${ }^{1}$

'Significant' they may well have been, but is there any evidence that they constituted a 'large part of the audience'? Certainly this does not seem to be the case during Shakespeare's career in the theatre, and it is equally questionable whether female spectators had any appreciable influence on female representation during his lifetime.

\section{Paucity of Direct Evidence}

Most of these critics rely on Andrew Gurr's detailed and scholarly study, recently revised, which concludes that:

the wives of citizens were regular playgoers throughout the whole period... Ladies went relatively rarely to the common playhouses before 1600 , but were in numbers at the Globe from 1599 to 1614 , and had become a major section of the audience at the indoor venues by Caroline times. ${ }^{2}$ 
Notwithstanding the great virtue of Gurr's book in that he lays out in his appendices the evidence on which the reader can make his own judgements, assessing the proportion of women in the audience during Shakespeare's working lifetime remains more fraught with problems than this statement suggests.

Shakespeare was writing between c. 1589 and c. 1614 and it is important to observe these parameters with some assiduity in any discussion of how contemporary theatre mores might have affected his writing, since it is all too easy to slip into the habit of talking of the whole period from 1576 to 1642 as the 'Shakespearean Stage', with its concomitant 'Shakespearean Audience', titles often pressed on the scholar by commercial considerations but suggesting a continuity of ethos and practice that is highly questionable. Such oversimplifications are made all the more tempting by the wealth of audience evidence from the period after Shakespeare's death in 1616, (and significantly most of the references to female spectators in prologues and epilogues, for instance, come from the 1620s and 1630s), all of which material must be put aside in determining the status of the female playgoer during the period when Shakespeare was writing.

Gurr provides two appendices, the first listing all the individuals known to have attended the theatre, and the second compiling general and literary references to audience composition. Of the 116 people listed in the first, known to have attended plays before 1615 only twelve of them are women, and one of these the female transvestite Moll Frith, whilst of the 114 literary or non-specific references to spectators in the second before 1615, again only twelve mention women other, that is, than prostitutes, who can be left aside as a special category of woman exclusive to male company who are unlikely to have had any significant effect on the gender balance of an audience (and Jonson's claim in the Prologue to Epicoene that the play caters for amongst other groups the 'daughters of Whitefriars' is surely meant to be satirical ${ }^{3}$ ).

It can be argued that part of this imbalance is due to the circumstances in which records of visits have been passed down. Most such evidence comes from printed matter, written by men, as was also the case with most of the diaries and correspondence. Many of the visitors are noted for what might be called gender-specific reasons. Ten are directly associated with the theatre, mostly playwrights. Thirteen of the visitors are foreigners, mostly dignitaries. Many of the references (more than a third) relate to incidents that brought theatregoers to the notice of the law, as rioters, thieves, victims, as conspirators in the Essex rebellion, or later in gentlemanly brawls. As Gurr acknowledges, 
the lack of commonplace evidence of ordinary people of either gender who just came and enjoyed the plays is most sorely missed. Indeed, unproblematical assumptions of women's presence are most valuable, such as Edmund Spenser's passing reference in The Faerie Queene:

All suddenly they heard a troublous noyes,

That seemd some perilous tumult to desine

Confusd with women's cries, and shouts of boyes,

Such as the troubled Theaters oftimes annoyes. (Book 4, Canto 3,

Excluding records of misbehaviour and of special visitors still leaves ten times as many references to men attending the theatre as women before 1615 and perhaps six times as many thereafter.

\section{The Good Woman}

Although Jean Howard argues that 'Plays for the public stage were not, by and large, overtly homiletic', and nor were they 'committed to the straightforward promulgation of dogma, ${ }^{4}$ nonetheless a survey of the 160 or so extant texts from the adult theatre of this period indicates that dogma was promulgated on a fairly wide front. As well as expressing a good deal of straightforward misogyny, these plays reveal a pervasive male didacticism most often expressed through polarised, stereotypical models of passive virtue and object lessons in the folly of rebellion. ${ }^{5}$

In Patient Grissil, Dekker's version of this classic account of the obedient wife, the first sixteen years of the heroine's marriage are one long cruel trial, which she passes with flying colours and apparently no permanent psychological damage. How a Man May Choose a Good Wife from a Bad, The London Prodigal, and The Fair Maid of Bristow are all part of a series of plays inculcating wifely virtues, concerning husbands who spurn their loving wives in favour of loose living, even plotting to kill them in order to marry prostitutes. Each is saved from justice and brought to repentance and reconciliation by the constant goodness of his wife, who puts up with any injury, even to offering her own life as a sacrifice for his. Although Shakespeare does not contribute directly to this altogether silly genre, a number of his patient and abused wives, both before and after marriage, are depicted with a similar degree of idealised, selfless, and unreciprocated faithfulness, including Hermione in 
The Winter's Tale, Hero in Much Ado, Queen Katherine in Henry VIII, and Desdemona in Othello. He is fond too of the Roman matron whose values are held up for admiration in many of the plays, and are closely related to the willingness of such to commit suicide to maintain their reputations. Portia in Julius Caesar, having stabbed herself in the side to prove her constancy, is reported taking her own life by eating hot coals. The heroine in the Rape of Lucrece, and again in Bonduca, together with her daughters, as well as Lucina in Valentinian, all die rather than face the shame of the violence done to them. The playwrights however were also inclined to recommend to their female spectators in line with the new emphasis on marriage and the home the more domestic Roman virtues of a good wife. So Virgilia in Coriolanus will not step abroad in her husband's absence; whilst Antony is away Octavia will spend her time praying on her knees for him; and in a series of plays by Heywood, How a Man May Choose a Good Wife from a Bad, 1 Edward IV, and The Rape of Lucrece, heroines are seen supervising households and voluntarily abasing themselves by following a narrow, restricting, huswifely code.

For the truly good wife, marriage in the plays is a moral absolute such that she can accept anything her husband does, however evil or unpleasant, even, like Eudoxia the Empress in Valentinian, murder in revenge when her husband's own initial crime was greater than the wrong done to him. In James $I V$ Dorothea is loyal to her marriage vows and to her husband even after he has attempted to have her assassinated. Such is the value placed upon marital chastity in the plays that wives are prepared to sacrifice not only their own lives, but the lives of others to avoid being dishonoured, in George A Greene Jane Barley her little son, and Katherine Sforza in The Devil's Charter her two sons, whilst in The Death of Robert, Earl of Huntingdon Matilda sees whole armies killed rather than yield her virtue to King John.

Wifely goodness can also be seen as a tangible thing, irrepressible, converting the most dissolute of prospective ravishers, as in Heywood's Royal King and Loyal Subject, and Dekker's Match Me in London and If It Be Not Good, the Devil Is In It. A regular plot in romantic comedies such as John of Bordeaux, A Knack to Know an Honest Man, and The Weakest Goeth to the Wall concerns wives abandoned under some compulsion, then subjected to threats and temptations but who, protected by an inner virtue, always remain true to their lost husbands, leading to a final reunion. Analogous to this loyalty is the impervious purity that protects the virgin Marina in the brothel in Pericles and Bess Bridges in her many predicaments in Fair Maid of the West. This extreme investment in marital chastity seems to have invented a new mode of 
death where a woman is so consumed with shame that she dies of it, as does Lucina after her rape by the Emperor in Valentinian, prompted to it by her own husband.

One indication that many of these plays are part of a polemical struggle between the sexes lies in their treatment of cuckoldry. It stands to reason that for every adulteress there must be a cuckold, and yet there are very few conventional cuckolds in the adult repertory. The few plays which do present a man successfully cuckolded are not surprisingly city comedies, mainly a private theatre genre for the children's troupes in which women become a commodity in the merchant's obsession with fleecing the gallant, but almost all adult theatre versions of this genre, such as The Family of Love, Bartholomew Fair, and The Roaring Girl, are subject to a sleight of hand that prevents the husbands from becoming actual cuckolds. One exception is the absurdly complacent cuckold in A Chaste Maid in Cheapside who makes a substantial living from his humiliation. Usually, the women are all too ready to betray their husbands, but the husbands somehow contrive to outwit them, or at any rate are saved by events from this humiliation.

In the main body of plays however in which adulteresses are featured, the authors work hard to minimise any negative fall-out on the husbands. If a woman takes to adultery, it is because she is a monster and therefore her husband is hardly to blame. Most adulteresses in the public theatre are seen as alien threatening creatures, lascivious, frightening, unnatural in their promiscuity, which is often augmented by some further crime. The Duchess in The Revenger's Tragedy is monstrous in choosing to betray her husband with her bastard stepson. Tamora in Titus Andronicus adds spice by cuckolding the Emperor with the black lover she brings with her. Artesia in The Birth of Merlin, described as 'that woman fury', failing in her attempts to woo Uther, accuses him of attempted abduction, and finally, hurling imprecations, is taken off to be walled up alive. There is an almost automatic association of adultery and murder. Queen Argiale in The Blind Beggar of Alexandria has killed the hero's wife in order to try to get him to submit to her. Aluida in A Looking Glass for London kills her husband in order to become the king's paramour. Livia, mistress of the hero in Sejanus, discusses how her husband should be murdered. Lucretia Borgia in The Devil's Charter puts away her third husband and pretends to mourn him. In Lust's Dominion the Queen Mother strangles the Moor's wife in order to be legally married to him.

Such representations of the evil consequences of female rebellion are much less frequent than models showing how wives ought to behave. And it is not 
difficult to see why. Several plays in the adult repertory have lustful adulteresses who finally repent, such as the Queen Mother in Lust's Dominion, and Leuidulcia in The Atheist's Tragedy. Their repentance however is arguably out of character and can be seen as a betrayal of the resilient worldliness of the main part of the play, and as with other spirited women shown receiving the wages of sin, such as Venus in The Cobbler's Prophecy, burned to death, and Julia poisoned for her curiosity in The Duchess of Malfi, there is always a danger of their punishment or repentance being dismissed as part of the conventional conclusion, leaving the female spectator free to savour the loose woman's earlier joie de vivre, and thus justifying Northbrooke and other puri$\tan$ enemies of theatre when they ironically invite their readers to go to the theatre to 'Learn how' to commit the many and varied sexual crimes represented there. Heywood's solution to this dilemma is to create in Edward IV and $A$ Woman Killed with Kindness a polemical hybrid, the innocent adulteress, who is also a sensitive moral creature unable to obtain satisfaction from her crime and instead suffering constantly for her lapse. Indeed, given that many of the lost plays from this period were written by Heywood, the most prolific dramatist of his time and master of polemic, who claimed to have had a 'maine finger' in 220 plays, only thirty or so of which are extant, whilst Dekker, the other main polemicist, is said to have written at least 64, the influence of this kind of drama may well have been even wider. No doubt, as Howard says, 'the process of ideological interpellation and control was never perfectly achieved', but the plays in the surviving canon in which so many of the female characters are didactic constructs urging unreal images of women, flattering or disparaging, suggest that, at least before the adults moved indoors, women playgoers had little appreciable effect in modifying the received male theatre tradition which polarised, marginalised, and subordinated its female characters. ${ }^{6}$

\section{Male Performance of the Female Roles}

One obvious reason for the failure of much modern criticism to recognise the constructed, polemical nature of Elizabethan characterisation has been its willingness to ignore the original performers and their likely performance ethos, the implications of which were not lost on an earlier generation of critics. To Dorothy Richardson, for instance, writing in 1910: 'There was no reality in any of Shakespeare's women. They please men because they show women as men see them ${ }^{3}$ — whilst Virginia Woolf in 1920 opined: 
it is daily more evident that Lady Macbeth, Cordelia, Ophelia ... and the rest are by no means what they pretend to be. Some are plainly men in disguise; others represent what men would like to be, or are conscious of not being. ${ }^{8}$

The contributors to The Woman's Part, on the other hand, clearly preferred his female characters to be 'real' people capable of psychological analysis and, above all, in need of defence, because, as its Introduction makes clear, its intentions were to pursue 'the struggle for women to be human in a world which declares them only female'. ' Gayle Greene exonerates Cressida, who 'reminds us of the effects of capitalism on women', ${ }^{10}$ and in a widespread misunderstanding about the nature of stage dialogue, Rebecca Smith would have Gertrude as other than Hamlet and the Ghost describe her, as if the characters could somehow have an existence separate from what they said and did and what was said about them. ${ }^{11}$ The book's contributors set out to liberate imaginary characters not only from critical misinterpretations but also from Shakespeare too, as Paula Berggren, talking of Imogen, Viola, and Rosalind:

When the disguises donned for protection expose them instead to unexpected danger, the heroines stand their ground as males despite the onrush of that stereotype "feminine" apprehension with which Shakespeare seems to signal their forthcoming return to their true selves. ${ }^{12}$

Quite how Rosalind's fainting could be called 'standing her ground' is difficult to see; nor Viola, who, aware of the 'little thing' she lacks, prays for God to defend her.

The Woman's Part is only one of many such exercises in which even the she-wolves have their crimes shuffled off. Irene Dash dismisses the unnatural behaviour of Queen Margaret in Henry VI with scarcely more than a tinge of censure: 'Unfortunately Margaret has assimilated patriarchal values'. ${ }^{13}$ Paula Berggren shrugs, 'Lady Macbeth ... is caught in a web that crippled women in a paternalistic society' - a strange defence for a woman who so much takes the initiative-whilst Coppelia Kahn argues Macbeth's wife attempts to mould him because, like Volumnia, it is 'the only power their cultures allow them'. ${ }^{14}$ Only finally does such defence become self-evidently unsupportable when it reaches King Lear. 'Are there any women in King Lear?' asks Ann Thompson. The unspoken answer is surely, 'No', and she cites Kathleen McLuskie: 'Feminism cannot simply take the "woman's part" when that part has been 
so morally loaded and theatrically circumscribed', 15 a judgement that applies equally one would have thought to all the aforementioned characters.

Similarly the determination to make the breeches role sympathetic to modern views about gender fluidity once again ignores the performance dimension. On the face of it, as Catherine Belsey and Ann Thompson both suggest, whenever one sex is imitated by another, however orthodox the ostensible purpose, the very process is likely to call gender assumptions into question and even more so, it might be imagined, in breeches roles where the layers are increased to three or even four. ${ }^{16}$ The practical considerations of performance however, in which a male actor plays a girl character dressed in men's clothes, requires that both dramatist and actor keep 'her' travestie constantly before the audience. This involves emphasising her femininity, and contrasting it with her lack of masculinity, and inevitably therefore of using the received stereotypical indicators to do so; as Madelon Sprengnether points out, 'the representation of sexual difference by male actors ... permits a wholly male definition of femininity'. ${ }^{17}$ Paradoxically, therefore, a female character in breeches is likely to be presented as more conventionally feminine than one in female dress. ${ }^{18}$ Several dramatists show this in action. In The Four Prentices of London, when the two heroines find themselves menaced by what they think is a predatory soldier, it is the one in skirts who takes the initiative:

[Enter the Ladies flying, pursued by the Clown]

FRENCH LADY: I wear a weapon that I dare not draw:

Fie on this womanish fear, what shall I do?

BELLA FRANCE: Some of my father's spirit revives in me,

Give me thy weapon, boy, and thou shalt see,

I for us both will win sweet liberty.

CLOWN: I was never so over-reached; and, but for my shame, and I am a

man-art-

arms, I would run away, and take me to my legs. Have at thee sweet lady. ${ }^{19}$

Even if Shakespeare had held and wished to express more radical views about gender equality, it is not at all clear that his plays would have provided the means to do so. For Jean Howard to argue that Rosalind 'reveals the constructed nature of patriarchy's representations of the feminine', or Madelaine Gohlke to suggest that Shakespeare's tragedies are a 'vast commentary on the absurdity and destructiveness' of the 'structures of male dominance', or 
Penny Gay to claim that As You Like It effects a 'thorough deconstruction of patriarchy and its gender roles', takes no account of the circumstances in which the plays were written and performed. ${ }^{20}$ The dramatist was an employee of the company, and Shakespeare almost certainly writing his earliest plays as a hired man. The plays were the company's assets and were not written for anything other than performance. In general they were only printed when a company was in difficulties, or, since no adequate copyright laws existed, to prevent rival performance, or when the particular play had ceased to be part of the company's repertoire. Thus the option of addressing another perhaps more discriminating public of readers was not open to a company playwright. The normal procedure, as G.E. Bentley demonstrates, was for the senior members of the company to monitor closely the development of the scripts on which so much of their livelihood depended. ${ }^{21}$ In particular there was close state censorship and a business-orientated company would want to avoid the delays involved in giving offence. Is it really likely then that such circumstances would be receptive to a 'vast commentary on the absurdity and destructiveness' of the 'structures of male dominance'? The whole Shakespeare-as-feminist project is predicated on an autonomous creative process that never existed. ${ }^{22}$

Much criticism still assumes the female roles were played by Granville Barker's 'boy-actress', a theory, drawing much on Ariel and his spirit servers, which conveniently subordinates everything else to the text. Barker requires of them a 'self-forgetful clarity of perception'. ${ }^{23}$ Using the boy actor, according to Juliet Dusinberre, means that 'The personality and the image of the actor does not interpose itself between the playwright and his conception of character'. ${ }^{24}$ Although more recent critics have concentrated on the supposed homosexual ethos of the Elizabethan cross-dresser, they too have not questioned his pre-pubescence. There is plenty of evidence, however, to show that some of these performers, perhaps all who played leading female roles, were in their late teens and even early twenties. They may well have also played male roles, and were sometimes integrated into the companies at a higher level than has generally been assumed.. ${ }^{25}$ Hence they were of an age to have made a considerable contribution as collaborators in shaping Shakespeare's conception of the characters.

Isidore of Seville writing in the seventh century glosses 'Histriones' as 'those men, who, dressed in female garb, mimicked the behaviour of loose women'. Nearly a quarter of the Elizabethan repertory features prostitutes and analogous loose women, towards whom, in an exclusively male tradition of per- 
formance that goes back to Roman times, male playwrights express considerable ambivalence. ${ }^{26}$ The developing tradition in Shakespeare's hands seems to have exploited the capacities of young men to present cross-gender roles: first mannish viragoes and shrews, and then benign breeches roles and unnatural cruel she-wolves, but it is not one that shows any signs of being receptive to the sorts of female influence that some modern commentators have imagined. The late adolescent performer was more capable of empathy perhaps than a younger player, but often mockingly satirical, ultimately disengaged from the roles he played and a spokesman for the male point-of-view, employed to celebrate the rich, exciting, often dangerous possibilities of the opposite sex, but also concerned to keep women in their place.

\section{The 'Exemplary’ Female Spectator}

Where women's presence is 'remarked', as Kathleen McLuskie points out, it is generally as a target for sexual interest. ${ }^{27}$ What further confuses the evidence here is the Elizabethan practice of using the term 'whore' and some of its cognates both to refer specifically to women who sell their bodies for sex and to those whose behaviour merely transgresses current proprieties. Are John Lane's 'light-tailed huswives', for instance, prostitutes, or merely citizens' wives out for a good time? ${ }^{28}$ Nor need the transgression be of itself sexual. Gurr's list of playgoers in the period before 1615 includes a whole series of women, like Joan Drake who put up resistance to her spiritual reformation; Moll Frith who wore men's (mainly) top garments; Lady Anne Halkett who seems to be defending herself against charges of parental disobedience and who organised all-girl trips to the theatre; Anne, Countess of Newport, whose scandal involved a conversion to Catholicism; and Elizabeth Wybarn whose husband died early in 1612 and who took a party to the Globe in the August of that year-all women who in some sense seem to have pleased themselves and thereby shown a degree of social independence, which in this society's eyes was a sure indicator of sexual waywardness.

Dympna Callaghan goes further and suggests that to the Elizabethans the very spectatorship of women was in a sense sexual. ${ }^{29}$ Thus women in the theatre, according to Gosson are subject to 'a kind of rape of the mind', whilst Munday talks of women being 'inflamed euen vnto furie' by 'spectacles of strange lust'. ${ }^{30}$ Hence women's more visible and audible response to events on the stage produced what Callaghan calls the 'exemplary spectator', one whose reactions keyed the rest of the audience. ${ }^{31}$ This does not mean, how- 
ever, that there were necessarily very many such women. Perhaps their very scarcity makes them more notable. As with Jean Genet's insistence that at performances of The Blacks there should be at least one white spectator, and in his absence a symbol of one, ${ }^{32}$ so too it might be argued that the quantity of misogyny and didacticism in Elizabethan plays also required only a notional constituency of women, thereby given a higher profile in epilogues and reports, but not necessarily in any great numbers.

\section{City Wives and the Anti-theatricalists}

There are only twelve entries in Gurr's Appendix 2 that refer to women in the audience during Shakespeare's career. Of these, in respect of the years before 1600 , there are just six, and apart from Spenser's theatrical simile mentioned above, four of the remaining five references are contained in anti-theatrical diatribes. These are widely cited as though genuine evidence in which one supposed enemy of the stage is taken to corroborate another, but in reality as well as drawing much of their material from Roman theatre and Dark Age polemicists (the latter with no direct experience of any kind of performance) rather than from the contemporary stage, they often merely copy from one another and so a single reference in the copious Northbrooke to the impropriety of female theatre-going, for instance, mentioning city wives, is likely to be repeated in turn by each of his successors; whilst Anthony Munday's claim that a number of citizens' wives admitted on their deathbeds that they committed adultery because of what they had seen at the theatre, albeit that Heywood offers similar examples in its defence, takes a good deal of swallowing. These diatribes are a form of perhaps peculiarly protestant entertainment, crafted by professional writers in a tradition that continues into our own tabloid press, seeking out enormities, railing against the times, and imbued most obviously in those writers who allegedly take up cudgels on the theatre's behalf like Lodge, Nashe, and Greene with an older tradition of 'flyting', of amusing insults and invective, that goes back to the Roman Saturnalia. The anti-theatrical writers Gosson and Munday, for instance, had themselves been both players and playwrights, and there is a strong sense of their wanting to keep the controversy going because it was profitable. Sincerity is not necessarily at a premium in this tradition, and certainly not factual accuracy. Thus Richard West in 1608, casting around for satirical targets, finds an easy one in the merchant's wife who visits plays and, he alleges, has her picture up in 
a bawdy house, but there is no reason to believe it is based on anything other than received prejudice.

But even if, as some modern critics claim, the anti-theatrical polemics are to be given credence as representative of more mainstream opinion, their interpretation is by no means straightforward. Although they do testify that city dames did attend plays, their vehement opposition to such activity indicates the level of prejudice such visits would have had to overcome and, if these opponents of theatre were as influential as is claimed, the dangers to reputations that theatre-going would have posed; all of which would suggest that the numbers of respectable women doing so would not be great. And this accords with the literary evidence. Representations of, or references to, citizen's wives attending the theatre by Beaumont (1607), Peacham (1622), and Glapthorne (1636) all suggest their infrequency. Beaumont's fictional grocer's wife in The Knight of the Burning Pestle, for instance, has nagged her husband for a whole year to be allowed to come to the theatre, and the satirical technique used is to make her completely ignorant of its conventions.

Since the sixth and final pre-1600 reference is Sir John Harrington's bawdy and most probably apocryphal tale of the lady torn between protecting her honour or her jewels, objective evidence of female theatre-going before 1600 is very thin indeed, and certainly does not justify the assertion that there was 'a plentiful supply of women playgoers ... throughout the period'. ${ }^{33}$

\section{The Male Ambience of Theatre During Shakespeare's Career}

Between 1594 and 1600, according to Gurr, contemporary testimonies 'indicate that the full range of society accepted ampitheatre playgoing'; yet the evidence as presented in his entries in Appendix 2 for this period suggests a much less heterogeneous ethos. ${ }^{34}$ In 1594, the Lord Mayor says theatres attract 'theeves, horsestealers, whore-moongers, coozeners' and others of that ilk.. In 1595, Harrington's great Lady is attacked by thieves. In 1596, the inhabitants of Blackfriars fear that if a theatre is allowed in their precinct it will bring 'all manner of vagrant and lewd persons'. In 1597, Joseph Hall's typical spectator for a Marlowe play is a 'base clown...his teeth in double rotten-row'. In 1598, a German spectator was robbed of 300 crowns at the Curtain; whilst another account in the same year notes 'many an old grey-bearded Citizen' sneaking from there into a brothel. In 1599, there is a complaint that the air is thick with tobacco fumes, and a report of a collapsed scaffolding at a puppet play mentions that of those killed, 'two [they say] were goode handsome 
whoores'. In 1600, Will Kempe records that when cutpurses are caught, they are tied to the post of the stage, and, all in the same year, John Lane complains of 'light-tayled huswives' that they 'show and vaunt' themselves at the Globe and Marston claims that a visitor to the ampitheatres risks being choked with the stench of garlic and pasted to the jacket of a brewer. ${ }^{35}$

Although there is plenty of reference in this sequence to visiting gallants and swaggerers, the general tone is of bawdry, pickpockets, and vulgar spectators, and although theatre-going is represented as an exciting risk for the respectable of either sex, it is certainly not an activity for a woman of any virtue. Other than whores, there is little direct evidence of women being present, apart from the satirical tale of the unfortunate great lady who saved her jewels at the cost of suffering an act of gross indecency. Whether or not the theatre during this period was really so disreputable is a different matter, but that is how these accounts, offered as evidence, choose to represent it.

Perhaps most significant, and generally ignored, are the large number of records that assume or imply a more or less exclusively male audience. Sir John Davies, for instance, describes an audience leaving the playhouse c.1593: 'A thousand townsemen, gentlemen, and whores, / Porters and serving men together throng. ${ }^{36}$ Such descriptions extend to the private playhouses. Commendatory verses to Beaumont's Faithful Shepherdess similarly describe the 1608 Blackfriar's audience at a boys' performance as 'a thousand men in judgement', who 'sit, / To call in question his undoubted wit'. ${ }^{37}$ Even more telling perhaps is Dekker's comprehensive list of audience types in 1609, mentioned en passant in describing the antics of his Gull, which includes not a single female category: 'Lords ... stinkards .... Your Gallant, your Courtier, and your Capten .... your Groundling, and gallery-Commoner .... the Farmers sonne... your Templer...your Car-man and Tinker' and 'the tribe of Critick'. ${ }^{38}$ Clearly it can rarely have been the case that women were completely absent even before 1600, but such descriptions as those above suggest that the dominant tone of the public theatre during Shakespeare's professional career was male. This was probably so especially in the open ampitheatres for which he wrote most of his plays, where the bulk of the audience stood in the yard, closely pressed together, descriptions of which, whilst not always being specific about the gender of 'gentle' spectators in the galleries, generally imply that the groundlings are (or again are predominantly) male. 


\section{Did Women go more frequently to the Indoor Playhouses?}

Many such descriptions stressing the supposed plebeian nature of public theatre audiences are drawn from the years following the reopening of the private playhouses after 1599, and these set out to emphasise by contrast the latter's social exclusiveness and gentility. Here, however, there is a contrast between the evidence in Gurr's Appendix 2 of literary and satirical references in which the remaining five items concerning female spectators before 1615, and all of them after 1600, set about suggesting that respectable female theatregoers were more likely to visit the indoor children theatres during this period, and the more strictly factual evidence of actual individual visits in Appendix 1, in which all seven women whose destinations can be identified before 1615, and five of these after 1609, went to public playhouses, mostly the Globe. It may have taken rather longer for women to begin to visit the indoor playhouses in any numbers than is sometimes assumed. There is certainly plenty of evidence of their presence after 1615 .

\section{Catering for Female Tastes}

One factor of significance which in some measure challenges the drift of the evidence so far presented, and is even less easy to quantify, is the subject matter of the plays ${ }^{39}$ and the presence of love as the dominant theme (as distinct from coupling as the hero's final reward). Where it is sympathetically presented and focuses on female feelings (and only Shakespeare's comedies really satisfy these criteria ${ }^{40}$ ), it has to be taken as some sort of indicator of the likely presence of female spectators; As You Like It even acknowledges them in its Epilogue. Women perhaps brought a new excitement to the theatre. There are commercial considerations too; a fashion for female play-going had the potential of doubling the size of the audiences. There are, however, only nine of his plays between 1593 and 1602 when they cease to be in vogue, from Two Gentlemen of Verona to All's Well That Ends Well, that could be described as romantic comedies, and interestingly this period also sees an increase in male polemic against women in the drama, especially after 1600, including the prodigal husband plays, Heywood's innocent adultresses, and Dekker's Patient Grissil and Honest Whore. Perhaps, and it can be no more than speculation, Shakespeare's love comedies of the 1590s, with their optimistic affirmation of female potential, mark an increase in and an encouragement for female spectating, leading thereby to the greater visibility of women in 
the theatre, which in turn stimulated both anti-theatrical rhetoric and more didacticism aimed at women in the plays of more conservative dramatists.

More significant perhaps in catering for this new development was the advent of John Fletcher. His output is complex and wide-ranging, but in plays like The Night Walker (1611), The Captain (1612) and Wit Without Money (1614), he developed a comic genre immensely important in the development (and trivialisation) of subsequent British theatre, anticipating the Restoration and much that came after, plays with smaller casts, a narrowing of scope, and diminution of social or political concern, in which women and the processes of wooing and coupling take centre place, but in a narrative tradition that is essentially contrived and soft-centred, harking back to the formulaic conventions of New Comedy. Fletcher learned a good deal from Shakespeare's women-their sprightliness, wit, and initiative, their vulgarity mixed with softness and concern, and he developed new ways of presenting female vulnerability in order to exploit what were evidently new market opportunities for addressing women (as well as men who liked women) in the private theatre audiences, and towards which the adult companies now turned their energies. It is however a genre that emerges only at the very end of Shakespeare's career, as the latter reviews in a more mellow frame of mind the themes of his tragedies, returning to the polarised stereotypes of ideal virtue and its obverse, but in romances quite unrelated to the brittle worldliness of Fletcher's comedies, which in this respect echo Middleton's children's plays.

\section{Conclusion}

It is difficult to form any firm conclusions from so much disparate evidence, but so far as the bulk of Shakespeare's career is concerned, records suggest that women occurred in relatively small numbers in the public theatres before 1615 and that there is no reason to suppose therefore that they had any great positive influence in determining the representation of female characters in adult plays much before that date, or can be blamed for the inadequacies thereof. It may well be as Gurr suggests that 'Citizen's wives were a noteworthy presence in the playhouses', but perhaps only because of the amount of negative comment made about them and their focus as an object for male polemic.

In any event, the issue of spectator numbers and that of their supposed influence on female representation are not necessarily related in the way often 
supposed. Just as the exemplary spectator might occasion more attention than her numbers justify, so larger numbers in themselves are no clear evidence of influence.

The modern parallel of cinema is all too available. Starting with Laura Mulvey in 1975, there has been a widespread objection from feminist critics that in many films the camera adopts the 'male gaze', objectifying the females in view. ${ }^{41}$ This interpretation in part may be an over-simplistic response to the cinema's reflection of a developing gender dichotomy of female display and male admiration in our society during the last two hundred years, but undoubtedly it has substance in the lingering views of the female body, sometimes used indeed to frame the picture. Female novelists may now be as successful and as numerous as their male counterparts, arguably coming into their own in a genre which in its contextualisation of human relations has always been popular with the female reader, but so far as enacted fiction is concerned, in film and television, too often women remain the objects of a male-orientated plot, just as in the Elizabethan theatre, symbols of loss, abuse, or admiration, and, pre-eminently, victims of eroticised violence. There is of course plenty of male-to-male violence in the dramatic fictions of both periods, but very little of the humiliation of the sort so prevalent towards women, which, however much it is deplored, evidently remains a source of widespread fascination. Indeed it is difficult to know how much purchase can be gained on the human psyche by condemning what it so avidly seeks.

Citing by way of a parallel Freud's essay on 'Femininity' in which he observes: 'to those of you who are women this will not apply-you are yourselves the problem', Mary Ann Doane asks, 'What, then of the female spectator?':

What can one say about her desire in relation to this process of imagining? It would seem that what the cinematic institution has in common with Freud's gesture is the eviction of the female spectator from a discourse purportedly about her (the cinema, psychoanalysis)—one which, in fact, narrativises her again and again. ${ }^{42}$

Although women have now begun to have some impact behind the camera, at least in art cinema, it remains the case that most of the fare intended for women is still made, so far as writing, direction and post-production is concerned, for rather than by them. ${ }^{43}$

There may be uncertainty about the numbers and status of female spectators in the Elizabethan theatre, but it can hardly be questioned that female 
cinema-goers today are at least as numerous as male ones, with far greater social recognition and economic power than their sixteenth century counterparts, and yet by-and-large they accept, and are subjected to, a medium of expression that still objectifies and thereby, it can be argued, inferiorizes them. We should not be surprised then to find such objectification and inferiorization were also often the case in the theatre for which Shakespeare wrote.

\section{Notes}

1 See S. Orgel, Impersonations, the Performance of Gender in Shakespeare's England (Cambridge, 1996), 11-13 and 72; R. Levin, 'Women in the Renaissance Theatre Audience, Shakespeare Quarterly 40 (1989), 165-74; L. Woodbridge, Women and the English Renaissance: Literature and the Nature of Womankind, 1540-1610 (Brighton, 1984), 251-2; A.Findlay, A Feminist Perspective on Renaissance Drama (Oxford, 1999), 1. The thrust of A. Cook, The Privileged Playgoers of Shakespeare's London (Princeton, 1981), however, is that theatre was primarily a male preserve.

2 A. Gurr, Playgoing in Shakespeare's London 3rd ed. (Cambridge, 2004), 76.

3 J.E.Howard, The Stage and Social Struggle in Early Modern England (London, 1994), 106f. and Findlay, Feminist Perspective, 109f. both assume it was a serious claim.

4 Ibid, 7, 109.

5 The following discussion is taken from Chapter 4 of D.A. Mann, Shakespeare's Women: Performance and Conception (Cambridge, February 2008).

6 There are of course many plays of the period which feature intelligent, resourceful women, like Moll Frith in The Roaring Girl, and others who cross-dress to serve the interests of their husbands like the redemptive Mistress Low-Water (No Wit, No Help Like a Woman's). But her willingness to go almost to penetration with Lady Goldenfleece is only an indication of the self-contained theatricality and performer bravado of Middleton's cross-dressed roles.

7 D. Richardson, Pilgrimage, Vol.2: The Tunnel (London, 1979 [1919]), 188.

8 Virginia Woolf, 'Men and Women' (1920), in Books and Portraits (London, 1977), 28-9.

9 C. Lenz et al (eds), The Woman's Part: Feminist Criticism of Shakespeare (Urbana, 1980), 3, citing Juliet Dusinberre, Shakespeare and the Nature of Women (1975), 93.

10 G. Greene, 'Shakespeare's Cressida', in Lenz, Woman's Part, 137.

11 R. Smith, 'A Heart Cleft in Twain', in Lenz, Woman's Part, 207-8. 
12 P.S. Berggren, 'The Woman's Part", in Lenz, Woman's Part, 27-8. See more recently Howard, Stage and Social Struggle, 114.

13 I. Dash, Wooing, Wedding, and Power: Women in Shakespeare's Plays (New York, 1981), 182.

14 Berggren, 'The Woman's Part', 27; and C. Kahn, Man's Estate: Masculine Identity in Shakespeare (Berkeley, 1981), 151.

15 A.Thompson, 'Are There Any Women in "King Lear"? in V. Wayne (ed.), The Matter of Difference: Feminist Materialist Criticism of Shakespeare (New York, 1991), 123; and K. McLuskie, 'The Patriarchal Bard' [1985], reprinted in K. Chedgzoy (ed.), Shakespeare, Feminism and Gender (Basingstoke, 2001), 40.

16 C. Belsey, 'Disrupting Sexual Differences: Meaning and Gender in the Comedies', in J.Drakakis (ed.), Alternative Shakespeares (London, 1985), 180; and A. Thompson, 'The Warrant of Womanhood: Shakespeare and Feminist Criticism', in G. Holderness (ed.), The Shakespearean Myth (Manchester, 1988), 81.

17 M. Sprengnether, 'The Boy Actor and Femininity in Antony and Cleopatra', in N.N. Holland, et al (eds), Shakespeare's Personality (Berkeley, 1989), 196.

18 Michael Shapiro, in Gender in Play on the Shakespearean Stage (Ann Arbor, 1996). perceives the contrast as between the actor as himself and as the female role, which presumably would be the more "feminine" of the two.

19 Mary Ann Weber Gasior (ed.), Thomas Heywood's The four prentices of London : a critical old-spelling edition (New York, 1980), p. 79, 11. 1760-72.

20 Howard, Stage and Social Struggle, 119; M. Gohlke, "I wooed thee with my sword": Shakespeare's Tragic Paradigms', in Lenz, Woman's Part, 162; P. Gay, As She Likes It (London, 1994), 49.

21 G.E. Bentley, The Profession of Dramatist in Shakespeare's Time (Princeton, 1971), 77.

22 Not all feminists, of course, take this view. Lisa Jardine, in Still Harping on Daughters (Sussex, 1983), for instance, is very critical of this approach, whilst Kathleen McCluskie shows how any performance of Shakespeare's plays, citing Measure for Measure, is inherently patriarchal. The audience may feel encouraged, for example, to sympathise with Angelo the rapist's dilemma rather than Isabella's cold indifference to her brother's plight.

23 H. Granville Barker, Prefaces to Shakespeare (1930; rpt London, 1963)., 1.17.

24 J. Dusinberre, Shakespeare and the Nature of Women (London, 1975), 269.

25 Hugh Clark became a sharer whilst still playing female roles, as did Ezekiel Fenn. Distinctions of grade were probably financial rather than artistic. John Rice, recorded in two civic pageants whilst with the King's Men, in 1607 as a 'very proper Child' and in 1610 as a nymph, the very next year became a sharer in Lady Elizabeth's. Older hired 
men certainly played burlesque females, and William Bird and Edward Collins may have continued to play female roles after they became hired men. D.Kathman. 'How Old Were Shakespeare's Boy Actors? Shakespeare Survey 59 (2005), 220-46, provides plenty of biographical details that show a common range of 15-22 years for players of female roles.

26 Mann, Shakespeare's Women, Chapter 5.

27 K. McLuskie, Renaissance Dramatists (Hemel Hempstead, 1989), 87fn.

28 John Lane, 'Tom Tel-Troths Message' (1600), ESTC 15190, 45.

29 D. Callaghan, Shakespeare Without Women: Representing Gender and Race on the Renaissance Stage (London, 2000) 24 and 142fn.

30 Levin, 'Women in the Renaissance Theatre Audience, 210; and Cook, The Privileged Playgoers of Shakespeare's London, 157-8

31 Callaghan, Shakespeare Without Women, 144.

32 M. Esslin, The Theatre of the Absurd (London, rev. 1968), 218.

33 Gurr, Playgoing in Shakespeare's London, 67.

34 Ibid, Appendix 2, item 11; Dekker's reference to 'A Play ... would ... fill a house with fishwives', is surely a piece of satirical hyperbole and not a serious piece of evidence.

35 Ibid, Appendix 2: 'Theeves, whore-mongers, cozeners', item 22.; Harington's great lady, item 25; 'All manner of vagrant and lewd persons', item 28; 'Base clown... his teeth in double rotton-row', item 29; 'Many an old grey-bearded citizen', item 33; complaint that the air is thick with tobacco fumes, item 36; 'Two were goode handsome hoores', item 38; Will Kempe's observation about cutpurses being tied to the stage, item 43; 'Light-tayled huswives', item 44; and Marston's claims that visitors risked being choked on the stench of garlic, item 46 .

36 'In Cosmum', 11. 7-8.

37 Beaumont's commendatory verse, 'To my friend Maister John Fletcher upon his faithful Shepheardesse', 11. 13-14, in Florence Ada Kirk (ed.), The Faithful Shepherdess (New York, 1980), 4.

38 Dekker, The Guls Horn-Booke, in Alexander B. Grosart (ed), The Non-Dramatic Works of Thomas Dekker (1885; rpt New York, 1963), 2.246-7.

39 Lorna Hutson concentrates on the clandestine marriage, arguing that it represents the idea of seductive male rhetoric rather than female rebellion. However in the majority of Shakespeare's romantic comedies there is little or no rhetoric and the female characters take the lead, cf. Juliet, Rosalind, Viola, and Helena. Lorna Hutson, The Usurer's Daughter: Male Friendships and Fictions of Women in Sixteenth-Century England (London, 1996).

40 For a play to provide evidence of this, it must show, rather than male wish- fulfilment, a genuine interest in love and the female point of view; it has to be prepared to give 
time to the process of love and its outcome-to anticipation, preparation, wooing, and yielding: 'Things won are done', Cressida says in Troilus and Cressida; 'Joy's soul lies in the doing' (1.2.287) —in short, love as process rather than product (G. Blakemore Evans (ed.), The Riverside Shakespeare (Bostom, 1974).

41 L. Mulvey, 'Visual Pleasures and the Narrative Cinema', Screen 16.3 (Autumn 1975). The contributors to L. Gamman and M. Marshment (eds), The Female Gaze (London, 1988) review the advances made up to that date to redress the balance, mainly within popular culture, but they remain slight. The real hope, as Mulvey pointed out, lies in technical developments that make film more 'artisanal' rather than capitalist, but control of distribution remains the issue; (though less fidelity to Freud's, surely redundant, analysis of female psychology would help).

42 Mary Ann Doane, 'Film and the Masquerade: Theorizing the Female Spectator', Patricia Erens (ed.), Issues in Feminist Film Criticism (Bloomington, 1990), 77.

43 Anne Ross Muir, 'The Status of Women Working in Film and Television', in Gamman and Marshment, The Female Gaze, 143-4, points out that there has actually been a decline in women's artistic involvement behind the camera since the 1930s and 40s, and that the $15 \%$ of the workforce that is female are largely absent from the wellpaid positions, artistic or technical, and 'buried in ghetto jobs' such as secretarial and production assistant employment. 